6 I.e. 431 Stevens Street, Camden, New Jersey.

7 In black ink the queried: "? five" interlined over the uncancelled "One".

8 In heavy black ink Whitman traced over the initial blue pencil entry, querying the new numbers: "Sands and Drift|at Sixty-?four/?five."

9 In blue pencil "two" mended over the initial "One."

10 If 1880 , Stafford's letter might have been written between the first week of January, when Whitman had returned from a trip to the West, to early June, when he again left Camden to visit Dr. Maurice Bucke in London, Ontario, and other places of interest, or from the beginning of October on, when he had returned to Camden from his travels. See Correspondence, 3:173, 180, et passim.

\title{
ANOTHER HARRY STAFFORD LETTER
}

In his above note on a recently discovered Harry Stafford letter to Whitman, Arthur Golden mentions another Stafford letter-in addition to the one that he printed - that did not appear in the collection of letters from Stafford to Whitman in Charley Shively's Calamus Lovers (San Francisco: Gay Sunshine, 1987), pp. 149171. This missing Stafford letter is in the Charles Sixsmith Collection at the John Rylands University Library of Manchester, England. ${ }^{1}$ It is written on a small card, and is in an envelope addressed, in Whitman's own hand, to "Walt Whitman London Ontario Canada" - he sent self-addressed envelopes to Harry and his family in order to encourage them to write while he was on his Canadian trip. ${ }^{2}$ The envelope is postmarked 17 July 1880 at Kirkwood, New Jersey. The letter actually consists of two messages, one written on top of the other in a palimpsest, with parts of the first message rendered unreadable by the second. The first message is as follows:

All are well at our place [unreadable word] received your papers \& letter in due issue. How long do you intend to stay in London and when do you think of returning to Camden? I must s[rest of word unreadable] on the day after you left was very [unreadable word]-surprised at [unreadable word] in departure. Hope to receive a letter from you soon. From your affectionate son, H. L. Stafford

Written across this message is the following, obviously added by Harry after he received another letter from Whitman:

Dear Walt-

Your postal received was glad to hear from you and learn you were well and enjoying yourself but sorry to hear that you were sick at last accounts. Your dear boy,

Harry

Although the initial message is tantalizingly unreadable in key parts, the letter is important for the suggestions of Stafford's emotional reaction to Whitman's departure. 


\section{NOTES}

1 Sixsmith was a member of the "Bolton College" group of British Whitmanites who met regularly, beginning in the 1880 s, to discuss Leaves of Grass; much of the Whitman material in the Sixsmith collection comes from Dr. Richard Maurice Bucke, who visited the Bolton group and sent them some materials that Whitman had left behind in London, Ontario, in 1880 when the poet had visited Bucke.

2 Another envelope in the Sixsmith collection, from Harry's brother Elmer, is self-addressed by Whitman, and the poet sent Harry's mother Susan an envelope on July 13, chiding the whole Stafford family for not writing (see Edwin Haviland Miller, ed., The Correspondence [New York: New York University Press, 1964], 3:184). 